\section{Basal Salt Composition, Cytokinins, and Phenolic Binding Agents Influence In Vitro Growth and Ex Vitro Establishment of Magnolia 'Ann'}

\author{
J. Kevin Parris ${ }^{1}$ \\ Clemson University, School of Agricultural, Forest, and Environmental \\ Sciences, Box 340310, Clemson University 29634, 164 Poole Agricultural \\ Center, Clemson, SC 29634
}

\author{
Darren H. Touchell ${ }^{4,5}$ and Thomas G. Ranney ${ }^{2}$ \\ Department of Horticultural Science, North Carolina State University, 455 \\ Research Drive, Mills River, NC 28759
}

\section{Jeffrey Adelberg 3 Clemson, SC 29634 \\ Additional index words. micropropagation, polyploidy, tissue culture}

Clemson University, School of Agricultural, Forest, and Environmental Sciences, Box 340310, Clemson University 29634, 164 Poole Agricultural Center,

\begin{abstract}
In vitro growth responses of Magnolia 'Ann' to basal salt composition, cytokinins, and phenolic binding agents were investigated in a series of experiments to refine micropropagation protocols. Murashige and Skoog (MS), half-strength MS, Woody Plant Medium (WPM), Driver and Kuniyuki (DKW), and Blaydes basal salts in conjunction with $1 \mathrm{~g} \cdot \mathrm{L}^{-1}$ activated charcoal (AC) or $1 \mathrm{~g} \cdot \mathrm{L}^{-1}$ polyvinylpyrrolidone (PVP) were evaluated as multiplication media. Benzylaminopurine (BAP), meta-topolin $(m \mathrm{~T})$, or $6-(\gamma, \gamma$-dimethylallylamino) purine $(2 \mathrm{iP})$ at 2,4 , or $8 \mu \mathrm{M}$ was investigated to optimize the cytokinin concentration. Murashige and Skoog medium supplemented with $2 \mu M$ BAP with no phenolic binding agent was an optimal multiplication medium that yielded $3.2 \pm 0.2$ shoots with a mean length of $17.2 \pm 1.8 \mathrm{~mm}$ over an 8-week period. For rooting, microshoots were cultured on half-strength MS media supplemented with 0,5 , 10, or $20 \mu M$ indolebutyric acid (IBA) with or without AC. Media containing AC produced elongated microshoots suitable for rooting and ex vitro establishment. Microshoots cultured on medium supplemented with $\mathrm{AC}$ also had higher in vitro rooting (16\%) and higher ex vitro rooting (75\%) compared with those without AC regardless of in vitro IBA concentration.
\end{abstract}

The genus Magnolia L. consists of over 250 species (Figlar and Nooteboom, 2004) and numerous hybrids and cultivars that can be cultivated in temperate and tropical climates worldwide. The diverse ornamental traits make the genus appealing for landscape use and

Received for publication 10 May 2012. Accepted for publication 4 Sept. 2012.

This research was funded in part by the North Carolina Agricultural Research Service (NCARS), Raleigh, NC.

Technical assistance of Jeremy Smith is gratefully acknowledged.

The research was from a MS thesis by the senior author.

Use of trade names in this publication does not imply endorsement by the NCARS of products named nor criticism of similar ones not mentioned. ${ }^{1}$ Graduate Research Assistant.

${ }^{2}$ Professor

${ }^{3}$ Professor.

${ }^{4}$ Research Associate.

${ }^{5}$ To whom reprint requests should be addressed; e-mail darren_touchell@ncsu.edu. breeding new cultivars. Magnolia [liliiflora 'Nigra' $(4 x) \times$ stellata 'Rosea' $(2 x)]$ 'Ann' (NA 28344; PI 326570) is a member of the "Little Girl" series of magnolias that have become very popular (United States National Arboretum, 2003). Magnolia 'Ann' is characterized by a desirable combination of traits including prolific and remontant flowering and a shrub-like form. Parris et al. (2010) confirmed $M$. 'Ann' to be a triploid $(2 n=3 x=$ $57)$ and the cultivar is sterile. In vitro propagation procedures may be an efficient means for rapid, large-scale production.

Previous micropropagation studies on Magnolia sp. focused on conservation efforts and included $M$. acuminata var. cordata (Michx.) Sarg. (Merkle and Wiecko, 1990; Merkle and Wilde, 1995), M. dealbata Zucc. (Mata-Rosas et al., 2006), M. denudate Desr. (Bi et al., 2002), M. fraseri Walt. (Merkle and Wiecko; 1990, Merkle and Wilde, 1995), M. macrophylla Michx. (Merkle and WatsonPauley, 1993; Merkle and Wilde, 1995), M. obovata Thunb. (Kim et al., 2007), M. officinalis Rehd. and Wilson. (Tong et al., 2002), M. pyramidata Bartram. (Merkle and Watson-Pauley, 1994; Merkle and Wilde, 1995), M. sieboldii Koch. (Lu et al., 2008), M. sinicum Law. (JunLi and Mingdong, 2007), and M. virginiana Linn. (Merkle and Wiecko, 1990; Merkle and Wilde, 1995). However, less research has been conducted on micropropagation of ornamental Magnolia taxa with the exception of M. × soulangeana Soul.-Bod. (Kamenicka and Lanakova, 2000; Maene and Debergh, 1985; Marinescu, 2008), M. grandiflora L. (Sakr et al., 1999; Tan et al., 2003), M. delavayi Franchet. (Luo and Sung, 1996). M. stellata Sieb. Zucc., and the hybrids 'Elizabeth' and 'Yellow Bird' (Biedermann, 1987). These studies indicated basal salt composition and plant growth regulators were important factors influencing in vitro propagation of magnolia.

Culture media comprised of Murashige and Skoog (1962) basal salts and vitamins have been widely used for in vitro propagation of magnolia (Biedermann, 1987; Marinescu, 2008). Merkle and Watson-Pauley (1993, 1994) used Blaydes modified basal medium (Blaydes, 1966) for somatic embryogenesis of Magnolia sp. Several alternative media compositions such as Driver and Kuniyuki (1984) walnut basal salt mixture and WPM (Lloyd and McCown, 1981) have been tested with a wide range of woody plant species with only limited investigations with Magnolia (Kamenicka and Lanakova, 2000).

Although several cytokinins have been used to induce shoot proliferation, BAP has been used most often for magnolia. For Magnolia $\times$ soulangeana, 1.2 $\mu \mathrm{M}$ BAP was shown to produce greater shoot proliferation than 2iP, kinetin, or thidiazuron (Marinescu, 2008). However, BAP has been shown to induce hyperhydricity, reduce shoot quality, and inhibit rooting in some taxa (Amoo et al., 2011; Bairu et al., 2007). Meta-topolin, a naturally occurring cytokinin similar in structure to BAP, has not been associated with hyperhydricity (Bairu et al., 2007; Werbrouck et al., 1996) and has been effective for micropropagation of many species (Amoo et al., 2011; Meyer et al., 2009).

Micropropagation of magnolia has been reported to be difficult because of the presence of phenolic substances (JunLi and Mingdong, 2007; Sakr et al., 1999). AC and PVP are used commonly in media to bind phenolics. Ascorbic acid was effective in micropropagation of Magnolia $\times$ soulangeana (Radomir and Radu, 2008) and may reduce oxidative processes that lead to phenolic accumulation. Although AC and PVP have not been evaluated for Magnolia, these have been effective phenolic binding agents (PBAs) used in micropropagation of many plant species (Roy, 1991; Thomas, 2008). The objective of the current study was to evaluate a range of basal media compositions, cytokinins, and PBAs to improve in vitro growth conditions for $M$. 'Ann' as a means for micropropagation and future ploidy manipulation. Ex vitro establishment protocols were also examined to ensure viable protocols exist to propagate plants or for commercial production. 
Table 1. Growth responses of Magnolia 'Ann' to different in vitro culture media and phenolic binding agents after 8 weeks.

\begin{tabular}{|c|c|c|c|c|c|c|}
\hline Media & Phenolic binding agent & Shoot number ${ }^{z}$ & Shoot length $(\mathrm{mm})^{\mathrm{z}}$ & Root number ${ }^{z}$ & Fresh wt $(\mathrm{g})^{\mathrm{z}}$ & Dry wt $(g)^{z}$ \\
\hline \multirow[t]{3}{*}{$\overline{\mathrm{MS}}$} & None & $3.2 \pm 0.2 \mathrm{a}$ & $17.2 \pm 1.8 \mathrm{c}$ & $0.2 \pm 0.07 \mathrm{de}$ & $5.6 \pm 0.60 \mathrm{~b}$ & $0.56 \pm 0.04 \mathrm{ab}$ \\
\hline & PVP & $2.8 \pm 0.3 \mathrm{ab}$ & $20.0 \pm 2.8 \mathrm{bc}$ & $0.1 \pm 0.10 \mathrm{de}$ & $4.8 \pm 0.45 b$ & $0.58 \pm 0.04 \mathrm{ab}$ \\
\hline & $\mathrm{AC}$ & $1.1 \pm 0.1 \mathrm{c}$ & $24.2 \pm 1.7 \mathrm{ab}$ & $0.6 \pm 0.03 \mathrm{bc}$ & $2.8 \pm 0.22 \mathrm{~cd}$ & $0.42 \pm 0.03 \mathrm{bcd}$ \\
\hline Half-strength & None & $2.8 \pm 0.2 \mathrm{ab}$ & $24.4 \pm 2.6 \mathrm{ab}$ & $0.3 \pm 0.14$ cde & $8.1 \pm 1.21 \mathrm{a}$ & $0.69 \pm 0.08 \mathrm{a}$ \\
\hline \multirow[t]{2}{*}{ MS } & PVP & $2.6 \pm 0.2 \mathrm{ab}$ & $19.9 \pm 1.1 \mathrm{bc}$ & $0.1 \pm 0.04 \mathrm{de}$ & $4.6 \pm 0.35 b c$ & $0.53 \pm 0.04 \mathrm{~b}$ \\
\hline & $\mathrm{AC}$ & $1.1 \pm 0.1 \mathrm{c}$ & $22.2 \pm 1.7 \mathrm{~b}$ & $0.3 \pm 0.08 \mathrm{cde}$ & $2.1 \pm 0.24 \mathrm{~d}$ & $0.35 \pm 0.03 \mathrm{~cd}$ \\
\hline \multirow[t]{3}{*}{ WPM } & None & $2.3 \pm 0.2 \mathrm{ab}$ & $19.9 \pm 1.9 \mathrm{bc}$ & $0.7 \pm 0.20 \mathrm{~b}$ & $2.4 \pm 0.38 \mathrm{~d}$ & $0.39 \pm 0.06 \mathrm{bcd}$ \\
\hline & PVP & $2.6 \pm 0.3 \mathrm{ab}$ & $16.5 \pm 1.6 \mathrm{c}$ & $0.4 \pm 0.19 \mathrm{bcd}$ & $1.9 \pm 0.57 \mathrm{~d}$ & $0.33 \pm 0.05 \mathrm{~d}$ \\
\hline & $\mathrm{AC}$ & $1.2 \pm 0.1 \mathrm{c}$ & $22.4 \pm 1.3 b$ & $1.8 \pm 0.16 \mathrm{a}$ & $2.4 \pm 0.16 \mathrm{~d}$ & $0.42 \pm 0.03 \mathrm{bcd}$ \\
\hline \multirow[t]{3}{*}{ DKW } & None & $2.6 \pm 0.4 \mathrm{ab}$ & $22.7 \pm 3.0 \mathrm{~b}$ & $0.1 \pm 0.04 \mathrm{de}$ & $4.9 \pm 1.07 \mathrm{~b}$ & $0.50 \pm 0.04 \mathrm{~b}$ \\
\hline & PVP & $2.9 \pm 0.4 \mathrm{a}$ & $19.0 \pm 1.0 \mathrm{bc}$ & $0.0 \pm 0.00 \mathrm{e}$ & $4.2 \pm 0.79 b c$ & $0.49 \pm 0.08 \mathrm{bc}$ \\
\hline & $\mathrm{AC}$ & $1.1 \pm 0.1 \mathrm{c}$ & $30.1 \pm 4.1 \mathrm{a}$ & $0.7 \pm 0.20 \mathrm{bc}$ & $3.0 \pm 0.53 \mathrm{c}$ & $0.29 \pm 0.04 \mathrm{~d}$ \\
\hline \multirow[t]{3}{*}{ Blaydes } & None & $1.2 \pm 0.2 \mathrm{c}$ & $8.2 \pm 2.1 \mathrm{~d}$ & $0.3 \pm 0.12 \mathrm{cde}$ & $2.2 \pm 0.24 \mathrm{~d}$ & $0.62 \pm 0.09 \mathrm{ab}$ \\
\hline & PVP & $1.5 \pm 0.2 \mathrm{c}$ & $13.6 \pm 3.2 \mathrm{~cd}$ & $0.1 \pm 0.11 \mathrm{de}$ & $2.2 \pm 0.44 \mathrm{~d}$ & $0.45 \pm 0.06 \mathrm{bc}$ \\
\hline & $\mathrm{AC}$ & $0.9 \pm 0.1 \mathrm{c}$ & $14.2 \pm 1.3 \mathrm{~cd}$ & $0.6 \pm 0.10 \mathrm{bc}$ & $0.9 \pm 0.16 \mathrm{~d}$ & $0.47 \pm 0.04 \mathrm{bc}$ \\
\hline \multicolumn{7}{|c|}{ Analysis of variance $\mathrm{y}^{\mathrm{y}}$} \\
\hline Media & & $* *$ & $* *$ & $* *$ & $* *$ & $* *$ \\
\hline PBA & & $* *$ & $* *$ & $* *$ & $* *$ & $* *$ \\
\hline Media $\times$ PBA & & $* *$ & NS & $* *$ & $* *$ & $*$ \\
\hline
\end{tabular}

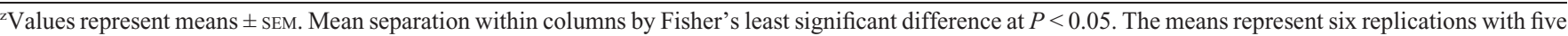
subsamples each.

$\mathrm{y}_{\mathrm{NS}}, * * *$ Nonsignificant or significant at $P=0.05$ or 0.01 , respectively.

$\mathrm{MS}=$ Murashige and Skoog basal salts and vitamins; WPM = woody plant medium basal salts and vitamins; DKW = Driver and Kuniyuki walnut basal salts and vitamins; Blaydes = Blaydes basal salts and vitamins; $\mathrm{PBA}=$ phenolic binding agent; $\mathrm{PVP}=$ polyvinylpyrrolidone; $\mathrm{AC}=$ activated charcoal).

\section{Material and Methods}

Plant material and culture conditions. Apical and axillary bud explants were used to initiate cultures. Actively growing shoots were collected from two-year-old fieldgrown plants and rinsed under tap water for $4 \mathrm{~h}$. Explants were surface-sterilized in a $20 \%$ (v/v) Ultra Clorox $(6.15 \% \mathrm{NaOCl})$ solution containing two to three drops of Tween 20 and periodically agitated for $17 \mathrm{~min}$ before three rinses in sterile distilled water for $5 \mathrm{~min}$ each. Explants were cultured on multiplication medium consisting of MS basal salts and vitamins supplemented with $2 \mu \mathrm{M}$ BAP, $0.1 \mathrm{~g} \cdot \mathrm{L}^{-1}$ myo-inositol, $0.1 \mathrm{~g} \cdot \mathrm{L}^{-1} 2$ (N-morpholino) ethanesulfonic acid (MES) monohydrate, and $30 \mathrm{~g} \cdot \mathrm{L}^{-1}$ sucrose. Media were adjusted to a $\mathrm{pH}$ of $5.75 \pm 0.03$ and solidified with $0.8 \%$ agar (Phytotech Laboratories). Media (25 $\mathrm{mL}$ ) was dispensed to $180-\mathrm{mL}$ glass jars. Proliferated shoots were used as stock cultures for all experiments and were maintained by transferring to fresh multiplication medium every 4 to 6 weeks and incubated under $23 \pm 2{ }^{\circ} \mathrm{C}$ and a 16 -h photoperiod of $70 \mu \mathrm{mol} \cdot \mathrm{m}^{-2} \cdot \mathrm{s}^{-1}$ (400 to $700 \mathrm{~nm}$ ) provided by cool-white fluorescent lamps.

Expt. 1: Media composition and phenolic binding agents. Effect of basal salt compositions and vitamins (MS, half-strength MS, WPM, Blaydes, and DKW) in factorial combination with PBAs (control, $1 \mathrm{~g} \cdot \mathrm{L}^{-1} \mathrm{AC}$, or $1 \mathrm{~g} \cdot \mathrm{L}^{-1} \mathrm{PVP}$ ) was examined. All media were supplemented with $30 \mathrm{~g} \cdot \mathrm{L}^{-1}$ sucrose, $2 \mu \mathrm{M}$ BAP, $0.1 \mathrm{~g} \cdot \mathrm{L}^{-1}$ myo-inositol, $0.1 \mathrm{~g} \cdot \mathrm{L}^{-1} \mathrm{MES}$ monohydrate, and solidified with $0.8 \%$ agar. Twenty-five milliliters of media were dispensed to 180 -mL glass jars. Five microshoots, $\approx 15$ to $20 \mathrm{~mm}$ long, were placed in each jar and incubated under culture conditions described previously. Each treatment consisted of six replicates (jars) containing five microshoots (subsamples) each for a total of 30 microshoots per treatment. All treatments

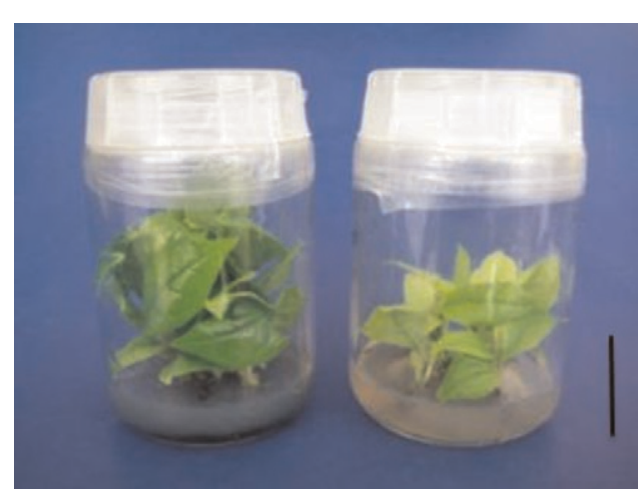

Fig. 1. In vitro growth of Magnolia 'Ann' microshoots with $2 \mu \mathrm{M}$ BAP plus AC (left), and $2 \mu \mathrm{M}$ BAP (right). When $\mathrm{AC}$ was incorporated in vitro, across all treatments, microshoots produced greener leaves and increased shoot lengths. Scale $\mathrm{bar}=4 \mathrm{~cm}$. BAP = benzylaminopurine; $\mathrm{AC}=$ activated charcoal.

were arranged in a completely randomized design. After 8 weeks, individual microshoots were scored for shoot number, shoot length (longest shoot), and root number. Fresh and dry weights were determined for the combined five shoots for each replicate. To determine dry weights, material was dried at $80{ }^{\circ} \mathrm{C}$ for $4 \mathrm{~d}$.

Expt. 2: Cytokinin concentration and activated charcoal. To investigate the interaction between cytokinins and $\mathrm{AC}$, the effect of $\mathrm{BAP}, m \mathrm{~T}$, or $2 \mathrm{iP}$ at 2,4 , or $8 \mu \mathrm{M}$ with or without $1 \mathrm{~g} \cdot \mathrm{L}^{-1} \mathrm{AC}$ was evaluated in a completely randomized design with a factorial arrangement of treatments. The basal media consisted of MS basal salts and vitamins, 30 g. $\mathrm{L}^{-1}$ sucrose, $0.1 \mathrm{~g} \cdot \mathrm{L}^{-1}$ myo-inositol, $0.1 \mathrm{~g} \cdot \mathrm{L}^{-1}$ MES monohydrate, and solidified with $0.8 \%$ agar. The experiment consisted of six replicates (jars) per treatment containing five microshoots (subsamples) per replicate arranged in a completely randomized design under culture conditions (as described previously). After 8 weeks, individual microshoots were scored for shoot number, shoot length (longest shoot), and root number. Fresh and dry weights were determined for the combined five shoots for each replicate. To determine dry weights, material was dried at $80{ }^{\circ} \mathrm{C}$ for $4 \mathrm{~d}$.

Data for both studies were subjected to analysis of variance (ANOVA) procedures (Proc GLM, SAS Version 9.1; SAS Institute, Inc., 2002). Means were separated by Fisher's least significant difference at $P<0.05$.

Expt. 3: Root initiation and acclimatization. Effects of IBAP concentration in combination with $\mathrm{AC}$ on rooting was investigated. Unrooted microshoots, $\approx 15$ to $20 \mathrm{~mm}$ long, were cultured on media consisting of halfstrength MS basal salts and vitamins, $30 \mathrm{~g} \cdot \mathrm{L}^{-1}$ sucrose, $0.1 \mathrm{~g} \cdot \mathrm{L}^{-1}$ myo-inositol, $0.1 \mathrm{~g} \cdot \mathrm{L}^{-1} \mathrm{MES}$ monohydrate, IBA at $0,5,10$, or $20 \mu \mathrm{M}, \mathrm{AC}(0$ or $\left.1 \mathrm{~g} \cdot \mathrm{L}^{-1}\right)$, and solidified with $0.8 \%$ agar. The experiment consisted of six replicates (jars) per treatment containing five microshoots (subsamples) per replicate arranged in a completely randomized design. After 6 weeks, microshoots were evaluated for number of roots and root length (longest root). Microshoots 
Table 2. Growth responses of Magnolia 'Ann' to different concentrations of cytokinins and phenolic binding agents in vitro after 8 weeks.

\begin{tabular}{|c|c|c|c|c|c|c|}
\hline Cytokinin $(\mu \mathrm{M})$ & Phenolic binding agent & Shoot number ${ }^{2}$ & Shoot length $(\mathrm{mm})^{\mathrm{z}}$ & Root number ${ }^{2}$ & Fresh wt $(\mathrm{g})^{\mathrm{z}}$ & Dry wt $(\mathrm{g})^{\mathrm{z}}$ \\
\hline \multirow[t]{2}{*}{4} & None & $2.63 \pm 0.2 \mathrm{a}$ & $19.5 \pm 0.5 \mathrm{abc}$ & $0.00 \mathrm{~d}$ & $1.97 \pm 0.2 \mathrm{ab}$ & $0.20 \pm 0.02 \mathrm{a}$ \\
\hline & $\mathrm{AC}$ & $1.06 \pm 0.04 \mathrm{~cd}$ & $17.7 \pm 0.9 \mathrm{bcdef}$ & $0.80 \pm 0.2 \mathrm{ab}$ & $1.56 \pm 0.3 \mathrm{bcd}$ & $0.17 \pm 0.02 b$ \\
\hline 8 & $\mathrm{Ac}$ & $1.14 \pm 0.1 \mathrm{~cd}$ & $18.3 \pm 1.2$ abcde & $0.8 \pm 0.3 \mathrm{a}$ & $1.16 \pm 0.1 \mathrm{de}$ & $0.14 \pm 0.01 \mathrm{bc}$ \\
\hline \multirow[t]{2}{*}{$m \mathrm{~T} 2$} & None & $1.40 \pm 0.1 \mathrm{c}$ & $14.1 \pm 1.0 \mathrm{~g}$ & $0.00 \mathrm{~d}$ & $0.9 \pm 0.2 \mathrm{e}$ & $0.11 \pm 0.01 \mathrm{c}$ \\
\hline & $\mathrm{AC}$ & $1.20 \pm 0.1 \mathrm{~cd}$ & $19.7 \pm 1.5 \mathrm{abc}$ & $0.67 \pm 0.3 \mathrm{bc}$ & $1.61 \pm 0.2 \mathrm{bcd}$ & $0.20 \pm 0.02 \mathrm{a}$ \\
\hline 8 & $\mathrm{AC}$ & $1.10 \pm 0.1 \mathrm{~cd}$ & $15.1 \pm 0.2 \mathrm{efg}$ & $0.00 \mathrm{~d}$ & $0.86 \pm 0.1 \mathrm{e}$ & $0.13 \pm 0.01 b c$ \\
\hline \multirow[t]{2}{*}{ 2iP 2} & None & $1.10 \pm 0.04 \mathrm{~cd}$ & $19.7 \pm 1.3 \mathrm{abc}$ & $0.00 \mathrm{~d}$ & $1.27 \pm 0.2 \mathrm{cde}$ & $0.21 \pm 0.04 \mathrm{a}$ \\
\hline & $\mathrm{AC}$ & $1.10 \pm 0.06 \mathrm{~cd}$ & $17.5 \pm 1.8 \mathrm{cdef}$ & $1.17 \pm 0.3 \mathrm{abc}$ & $1.54 \pm 0.1 \mathrm{~cd}$ & $0.18 \pm 0.02 \mathrm{ab}$ \\
\hline \multirow[t]{2}{*}{4} & None & $1.06 \pm 0.06 \mathrm{~cd}$ & $15.7 \pm 1.8 \mathrm{defg}$ & $0.17 \pm 0.2 \mathrm{~cd}$ & $0.87 \pm 0.1 \mathrm{e}$ & $0.13 \pm 0.01 \mathrm{bc}$ \\
\hline & $\mathrm{AC}$ & $1.20 \pm 0.1 \mathrm{~cd}$ & $18.9 \pm 0.7 \mathrm{abcd}$ & $0.83 \pm 0.2 \mathrm{ab}$ & $1.73 \pm 0.1 \mathrm{abc}$ & $0.22 \pm 0.02 \mathrm{a}$ \\
\hline 8 & None & $1.10 \pm 0.04 \mathrm{~cd}$ & $21.0 \pm 0.8 \mathrm{a}$ & $0.67 \pm 0.3 \mathrm{~b}$ & $1.72 \pm 0.1 \mathrm{abc}$ & $0.13 \pm 0.02 b c$ \\
\hline \multicolumn{2}{|c|}{ Cytokinin $\times$ concn. } & NS & NS & NS & NS & NS \\
\hline \multicolumn{2}{|c|}{ Cytokinin $\times$ AC } & ** & $*$ & ** & ** & ** \\
\hline \multicolumn{2}{|c|}{ Concn. $\times \mathrm{AC}$} & NS & NS & ** & $* *$ & NS \\
\hline \multicolumn{2}{|c|}{ Cytokinin $\times$ concn. $\times$ AC } & NS & NS & NS & ** & $* *$ \\
\hline
\end{tabular}

${ }^{2}$ Values represent means \pm SEM. Mean separation within columns by Fisher's least significant difference at $P<0.05$. The means represent six replications with five subsamples each.

${ }^{\mathrm{N}} \mathrm{NS}, *, * *$ Nonsignificant or significant at $P=0.05$ and 0.01 , respectively.

$\mathrm{BAP}=6$-benzylaminopurine; $m \mathrm{~T}=$ meta-topolin; $2 \mathrm{iP}=6$ - $(\gamma, \gamma$-dimethylallylamino $)$ purine; $\mathrm{AC}=$ activated charcoal at $1 \mathrm{~g} \cdot \mathrm{L}^{-1}$.

then were rinsed carefully with water to reduce transfer of sucrose to the soilless media. Microshoots were inserted with one leafless node placed below the surface of the media ( 2 peat: 1 vermiculite, v:v) in 50 -cell trays in a randomized block design and placed under intermittent mist (10-s duration at 10-min intervals). Data were collected on number of microshoots rooted, roots per plant, lateral root number, root length (longest root), and number of new leaves at 6 weeks ex vitro. Data were subjected to ANOVA procedures and regression analysis (Proc GLM, SAS Version 9.1; SAS Institute, Inc., 2002).

\section{Results and Discussion}

Expt. 1: Media composition and phenolic binding agents. Media composition, PBA, and their interactions had significant effects on shoot number, root number, fresh weight (FW), and dry weight (DW) $(P<0.01)$. Shoot length was affected by media composition and PBA main effects $(P<0.01)$ but not by their PBA interactions (Table 1).

Shoot proliferation was observed on MS, half-strength MS, WPM, and DKW with PVP or without PBA (2.6 to 3.2 shoots per microcutting). In contrast, use of AC as a PBA with these four media reduced shoot formation (1.1 to 1.2 shoots per microcutting). Microshoots cultured on Blaydes medium showed reduced shoot proliferation regardless of PBA. Similar interactions between PBA and media compositions influenced FW and DW. Fresh weights on half-strength MS, MS, and DKW without PBAs were relatively high $(8.1,5.6$, and $4.9 \mathrm{~g}$, respectively) but declined when $\mathrm{AC}$ was added to the medium $(2.1,2.8$, and $3.0 \mathrm{~g}$,

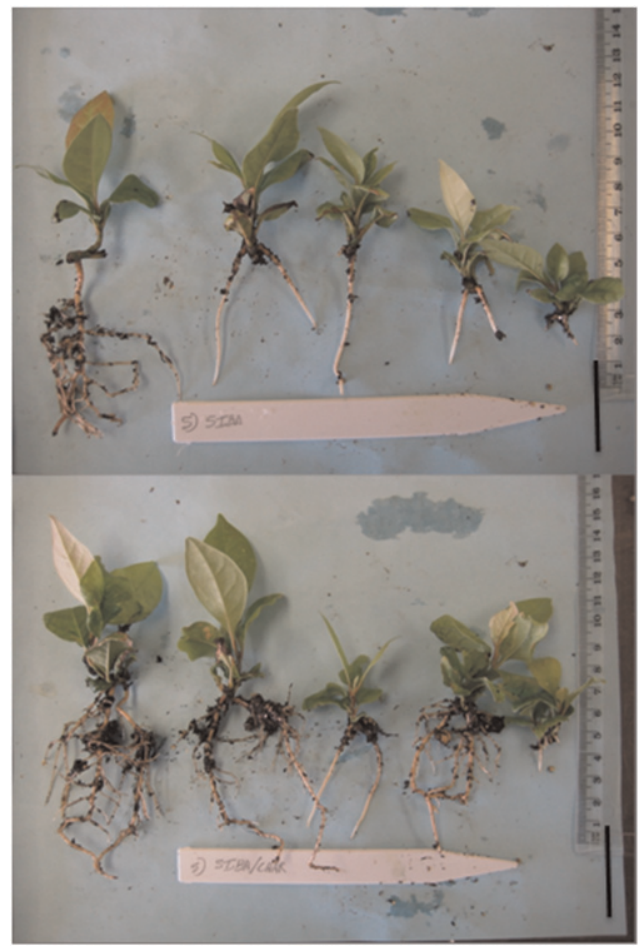

Fig. 2. Rooting and growth of Magnolia 'Ann' microshoots 6 weeks after treatment in vitro with $5 \mu \mathrm{M}$ IBA (A) and $5 \mu \mathrm{M}$ IBA plus $\mathrm{AC}(\mathbf{B})$. When $\mathrm{AC}$ was incorporated in vitro, across all treatments, roots were more frequent, more lateral roots were present, and more leaves were produced ex vitro. Scale bar = $4 \mathrm{~cm} . \mathrm{IBA}=$ indolebutyric acid; $\mathrm{AC}=$ activated charcoal.

respectively). Lowest $\mathrm{FW}$ was observed on WPM and Blaydes medium regardless of PBAs. Dry weights of microshoots showed a similar response to FW. Media composition and PBA also significantly impacted shoot length. Mean shoot lengths increased on all media compositions supplemented with AC, except for half-strength MS, with the longest $(30 \pm 4.1 \mathrm{~mm})$ on DKW. Shoot length remained low on Blaydes media regardless 
Table 3. In vitro and ex vitro rooting responses of Magnolia 'Ann' to exposure to activated charcoal (AC).

\begin{tabular}{|c|c|c|c|c|c|c|c|c|}
\hline $\begin{array}{l}\mathrm{AC} \\
\left(\mathrm{g} \cdot \mathrm{L}^{-1}\right)\end{array}$ & $\begin{array}{c}\text { In vitro } \\
\text { rooting }(\%)^{\mathrm{z}}\end{array}$ & $\begin{array}{c}\text { In vitro } \\
\text { root number }\end{array}$ & $\begin{array}{l}\text { In vitro root } \\
\text { length }(\mathrm{mm})^{\mathrm{z}}\end{array}$ & $\begin{array}{c}\text { Ex vitro } \\
\text { rooting }(\%)^{\mathrm{z}}\end{array}$ & $\begin{array}{c}\text { Ex vitro } \\
\text { root number }\end{array}$ & $\begin{array}{l}\text { Ex vitro root } \\
\text { length }(\mathrm{mm})^{\mathrm{z}}\end{array}$ & $\begin{array}{l}\text { Ex vitro lateral } \\
\text { root number }\end{array}$ & $\begin{array}{c}\text { Ex vitro } \\
\text { leaf number }\end{array}$ \\
\hline$\overline{0}$ & $2.5 \pm 0.4 \mathrm{a}$ & $0.5 \pm 0.1 \mathrm{a}$ & $0.4 \pm 0.4 \mathrm{a}$ & $49 \pm 4.6 \mathrm{a}$ & $0.95 \pm 0.1 \mathrm{a}$ & $15.4 \pm 1.8 \mathrm{a}$ & $0.8 \pm 0.3 \mathrm{a}$ & $1.2 \pm 0.1 \mathrm{a}$ \\
\hline 1 & $16.5 \pm 0.8 \mathrm{~b}$ & $4.4 \pm 1.0 \mathrm{~b}$ & $4.5 \pm 0.8 b$ & $74 \pm 4.7 \mathrm{~b}$ & $1.73 \pm 0.1 \mathrm{~b}$ & $44.8 \pm 2.0 \mathrm{~b}$ & $6.4 \pm 0.7 b$ & $2.0 \pm 0.1 \mathrm{~b}$ \\
\hline
\end{tabular}

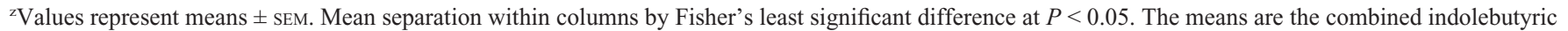
acid concentrations within each activated charcoal treatment and represent 24 replications with five subsamples each.

${ }^{y}$ Data were collected after 6 weeks of in vitro culture and microshoots (unrooted and rooted) were transferred to ex vitro. Ex vitro data were collected after an additional 6 weeks.

of the addition of PBA. While unintended, root formation was observed across all media compositions. Generally, there was an increase in root number with the addition of $\mathrm{AC}$ to the medium. Highest root formation (1.8 \pm 0.16 ) was observed on WPM supplemented with AC.

Activated charcoal is regularly added to media to adsorb inhibitory phenolics and oxidative exudates and to improve overall plant growth. However, in addition to adsorbing deleterious substances, AC may also adsorb plant growth regulators, vitamins, and nutrient ions as well as altering $\mathrm{pH}$ essential for plant growth and development (Thomas, 2008). Although microshoots of $M$. 'Ann' grown on media containing $\mathrm{AC}$ produced greener leaves and increased in shoot length, indicating binding of deleterious substances may improve plant growth, they also had reduced shoot proliferation and root initiation (Fig. 1). Similarly, black wattle (Acacia mearnsii De Wild.) microshoots cultured on media containing AC had reduced chlorosis, increased shoot elongation, and spontaneous rooting (Quoirin et al., 2001). Kang et al. (2009) attributed improved in vitro growth of Populus trichocarpa Torr. \& Gray. to increased chlorophyll content in microshoots cultured on media containing AC. Reduced shoot formation and increased shoot elongation were observed for microshoots of cashew (Anacardium occidentale L.) cultured on media containing AC (Boggetti et al., 1999). Ebert et al. (1993) reported that in media containing $0.25 \% \mathrm{AC}$, less than $2 \%$ of BAP was available after $3 \mathrm{~d}$. The strong adsorptive capacity of AC toward cytokinins, including BAP, is likely to have a significant impact on shoot proliferation (Ebert et al., 1993; Thomas, 2008).

Expt. 2: Cytokinin concentration and activated charcoal. There was a significant interaction between cytokinin and $\mathrm{AC}$ that influenced shoot number, shoot length, FW, and DW, whereas a complex interaction among cytokinin, cytokinin concentration, and AC affected fresh and dry weights (Table 2). In general, shoot number was highest on media containing BAP without AC. Microshoots cultured on media containing AC generally had reduced shoot numbers (Table 2). There were complex interactions between cytokinin and $\mathrm{AC}$ that influenced shoot length; however, in general, shoot lengths were reduced on media containing $m \mathrm{~T}$. Similar to the first study, addition of AC to the media promoted root formation. Fresh weight was generally higher on media containing BAP, whereas $\mathrm{AC}$ tended to reduce fresh and dry weight in all media except those containing 2iP (Table 2).
Shoot number of $M$. 'Ann' was greater on $\operatorname{BAP}(2.48$, mean for all concentrations) compared with either $m \mathrm{~T}$ (1.41) or 2iP (1.08). Marinescu (2008) reported higher proliferation rates using $2.5 \mu \mathrm{M}$ BAP compared with $2 \mathrm{iP}$, kinetin, or thidiazuron for M. × soulangeana. For M. liliiflora (a parent of $M$. 'Ann'), $2.22 \mu \mathrm{M}$ BAP produced proliferation rates and shoot lengths similar to our study on $M$. 'Ann' (Kamenicka et al., 2001). Similarly, in our first experiment, BAP produced proliferation rates of 3.2. The slightly higher rate we observed in the first experiment may be related to the age and condition of the stock cultures. These studies indicated BAP may be a suitable cytokinin for in vitro multiplication of Magnolia.

In the current study we report the investigation of $m \mathrm{~T}$ for in vitro propagation Magnolia sp. Meta-topolin has been reported to produce longer, greener, and less hyperhydrated shoots and may be an alternative cytokinin to BAP (Amoo et al., 2011; Werbrouck et al., 1996). Although microshoots of $M$. 'Ann' cultured on $m \mathrm{~T}$ had reduced moisture content, suggesting reduced hyperhydricity, they also produced a decreased number of shoots with reduced length.

Expt. 3: In vitro and ex vitro rooting and establishment. In vitro root formation was observed within 4 weeks of culture. Activated charcoal increased rooting percentage, number of roots per shoot, and shoot length after 6 weeks of in vitro culture $(P<0.05)$ (Fig. 2). Because the concentration of IBA and the IBA $\times$ AC interaction were not significant, results are presented for the effect of AC only (Table 3). Although AC improved in vitro rooting, only $16 \%$ of $\mathrm{AC}$ treated microshoots formed roots (Table 3).

Microshoots (rooted and unrooted) cultured on in vitro rooting media were transferred ex vitro. After 6 weeks ex vitro, root formation was observed for all treatments. In vitro AC treatment significantly increased rooting percentage, number of roots per plant, secondary root formation, and root length ex vitro $(P<0.05)$ (Table 3$)$. Similar to in vitro rooting, IBA concentration and the IBA $\times$ $\mathrm{AC}$ interaction were not significant and data are presented for the effect of AC only (Table 3). Plantlets from AC treatments also had more new leaves (Table 3 ).

Promotion of root development through in vitro $\mathrm{AC}$ treatments alone or in combination with auxin has been observed for numerous genera (Thomas, 2008). For example, stone pine (Pinus pinaster Aiton.) rooting increased from $21 \%$ to $78 \%$ with the addition of $20 \mathrm{~g} \cdot \mathrm{L}^{-1}$ AC (Dumas and Monteuuis, 1995). For sugar apple (Annona squamosa L.), rooting was observed when microshoots were cultured for 2 weeks in media containing $10 \mathrm{~g} \cdot \mathrm{L}^{-1} \mathrm{AC}$ before treating with auxin (Lemos and Blake, 1996). These studies suggested AC could promote rooting by adsorbing rooting inhibitors (Dumas and Monteuuis, 1995; Thomas, 2008). Activated charcoal also could provide a darkened environment at the shoot base simulating soil conditions and allowing for accumulation of photosensitive auxins (Dumas and Monteuuis, 1995; Thomas 2008). The present investigation on $M$. 'Ann' microshoots cultured on AC had increased root formation, greener shoots (data not shown), and improved growth when transferred ex vitro (Table 3). Kang et al. (2009) suggested that increased chlorophyll in microshoots cultured on media containing AC may increase overall fitness of micropropagated plants. Early root formation may also allow plants to sequester nutrients and improve ex vitro establishment (Kang et al., 2009).

For the present study on M. 'Ann', IBA (0 to $20 \mu \mathrm{M}$ ) did not influence rooting. In comparison, Kamenicka and Lanakova (2000) found a linear increase in root formation with an increase in IBA up to $20 \mu \mathrm{M}$ for $M$. × soulangeana. In contrast, for $M$. sirindhorniae, IBA concentrations of $60 \mu \mathrm{M}$ were most effective for promoting in vitro root formation (Chaidaroon et al., 2004). Therefore, future rooting studies on M. 'Ann' may need to investigate using higher concentrations of IBA.

This study describes development of a successful micropropagation protocol for M. 'Ann'. These procedures allow for rapid multiplication and successful ex vitro establishment. Further refinement of protocols should address optimal timing and duration of exposure to AC and increased IBA concentration to further enhance rooting and to test the applicability of these protocols to diverse Magnolia taxa. These protocols also provide a platform for future experiments focused on the development of allopolyploids to restore fertility by chromosome doubling.

\section{Literature Cited}

Amoo, S.O., J.F. Finnie, and J. Van Staden. 2011. The role of meta-topolins in alleviating micropropagation problems. Plant Growth Regulat. 63:197-206.

Bairu, M.W., W.A. Stirk, K. Dolezal, and J.V. Staden. 2007. Optimizing the micropropagation protocol for the endangered Aloe polyphylla: Can meta-topolin and its derivatives serve as replacement for benzyladenine and zeatin? Plant Cell Tissue Organ Cult. 90:15-23. 
Bi, Y., S. Gao, Y. Qiao, S. Liu, H. Cao, and H. Zhang. 2002. Effect of plant growth regulator on tissue culture of Mongolian white yulan. J. Hebei Vocation-Tech. Teachers College. 16: 14-15 (abstr.).

Biedermann, I.E.G. 1987. Factors affecting establishment and development of Magnolia hybrids in vitro. Acta Hort. 212:625-630.

Blaydes, O.F. 1966. Interaction of kinetin and various inhibitors in the growth of soybean tissue. Physiol. Plant. 19:748-753.

Boggetti, B., J. Jasik, and S. Mantell. 1999. In vitro multiplication of cashew (Anacardium occidentale L.) using shoot node explants of glasshouse raised plants. Plant Cell Rep. 18:456-461.

Chaidaroon, S., I. Ungvichian, and K. Ratanathavornkiti. 2004. In vitro root initiation of 'Champi Sirindhorn' (Magnolia sirindhorniae Noot. \& Chalermglin). Assumption Univ. J. Tech. Jan: 129-132.

Driver, J.A. and A.H. Kuniyuki. 1984. In vitro propagation of Paradox walnut rootstock. HortScience 19:507-509.

Dumas, E. and O. Monteuuis. 1995. In vitro rooting of micropropagated shoots from juvenile and mature Pinus pinaster explants: Influence of activated charcoal. Plant Cell Tissue Organ Cult. 40:231-235

Ebert, A., F. Taylor, and J. Blake. 1993. Changes of 6-benzylaminopurine and 2,4-dichlorophenoxyacetic acid concentrations in plant tissue culture media in the presence of activated charcoal. Plant Cell Tissue Organ Cult. 33:157-162.

Figlar, R.B. and H.P. Nooteboom. 2004. Notes on Magnoliaceae IV. Blumea 49:1-14.

JunLi, L. and M. Mingdong. 2007. Study on browning of endangered Manglietiastrum (Magnolia) sinicum in tissue culture. J. Zhejiang For. Sci. Tech. 27:20-23 (abstr.).

Kamenicka, A., A. Kormut'ák, and M. Lanakova. 2001. Establishing micropropagation conditions for three Magnolia species. Prop. Ornamental Plants 1:41-45.

Kamenicka, A. and M. Lanakova. 2000. Effects of culture medium composition and vessel type on axillary shoot formation of Magnolia in vitro. Acta Physiol. Plant. 22:129-134.

Kang, B-g, L. Osburn, D. Kopsell, G.A. Tuskan, and Z.-M. Cheng. 2009. Micropropagation of Populus trichocarpa 'Nisqually-1': The genotype deriving the Populus reference genome. Plant Cell Tissue Organ Cult. 99:251-257.

Kim, Y.K., Y.S. Park, I.S. Park, and H.K. Moon. 2007. Somatic embryogenesis and plant regeneration from immature seeds of Magnolia obovata. Plant Biotechnol. Rep. 1:237-242.

Lemos, E.E.P. and J. Blake. 1996. Micropropagation of juvenile and adult Annona squamosal. Plant Cell Tissue Organ Cult. 46:77-79.

Lloyd, G. and B.H. McCown. 1981. Commerciallyfeasible micropropagation of Mountain Laurel, Kalmia latifolia, by shoot tip culture. Proc. Intl. Plant Prop. Soc. 30:421-427.

Lu, X., S. Xu, T. Li, L. Zhang, and S. Gao. 2008. Embryo culture and rapid propagation of Magnolia sieboldii. J. Northeast For. Univ. 36:5-7 (abstr.).

Luo, G. and W. Sung. 1996. A brief report on micropropagation of a rare ornamental shrubthe red form of Magnolia delavayi. Magnolia 31:22-27 (abstr.).

Maene, L. and P. Debergh. 1985. Liquid medium additions to establish tissue cultures to improve elongation and rooting in vivo. Plant Cell Tissue Organ Cult. 5:23-33.

Marinescu, L. 2008. Preliminary results regarding the influence of cytokinin on the micropropagation of Magnolia soulangiana Soul. Bot. Bul. Univ. Agr. Sci. Veterinary Medicine. Seria B(LI). p. 601-607.

Mata-Rosas, M., A. Jimenez-Rodriguez, and V.M. Chavez-Avila. 2006. Somatic embryogenesis and organogenesis in Magnolia dealbata Zucc. (Magnoliaceaea), an endangered, endemic Mexican species. HortScience 41:325-329.

Merkle, S.A. and B.A. Watson-Pauley. 1993. Regeneration of bigleaf magnolia by somatic embryogenesis. HortScience 28:672-673.

Merkle, S.A. and B.A. Watson-Pauley. 1994. Ex vitro conversion of pyramid magnolia somatic embryo. HortScience 29:1186-1188.

Merkle, S.A. and A.T. Wiecko. 1990. Somatic embryogenesis in three magnolia species. J. Amer. Soc. Hort. Sci. 115:858-860.

Merkle, S.A. and H.D. Wilde. 1995. Propagation of Magnolia and Liriodendron via somatic embryogenesis. Proc. $8^{\text {th }}$ Intl. Congr. Plant Cell Cult. p. 117-222.

Meyer, E.M., D.H. Touchell, and T.G. Ranney. 2009. In vitro shoot regeneration and polyploid induction from leaves of Hypericum species. HortScience 44:1957-1961.

Murashige, T. and F. Skoog. 1962. A revised medium for rapid growth and bioassays with tobacco tissue cultures. Physiol. Plant. 15:473497.

Parris, J.K., T.G. Ranney, H.T. Knap, and W.V. Baird. 2010. Ploidy levels, relative genome sizes, and base pair composition in Magnolia. J. Amer. Soc. Hort. Sci. 135:533-547.

Quoirin, M., M.C. da Silva, K.G. Martins, and D.E. de Oliveira. 2001. Multiplication of juvenile black wattle by microshoots. Plant Cell Tissue Organ Cult. 66:199-205.

Radomir, A.M. and C.M. Radu. 2008. Research on behaviour of Magnolia soulangiana in the multiplication stage of 'in vitro' culture. Ornamental Plant Landscape Architecture. LI:258 261.

Roy, S.K. 1991. In vitro clonal propagation of two varieties of Artocarpus heterophyllus. Proc. Intl. Wkshp. Res. Multi-purpose tree species in Asia. Winrock International Institute for Agricultural Development. p. 125-132 (abstr.).

Sakr, S.S., M.A. El-Khateeb, and A.H. AbdelKareim. 1999. Micropropagation of Magnolia grandiflora L. through tissue culture technique. Bul. Faculty Agr. Univ. Cairo 50:283-298 (abstr.).

SAS Institute, Inc. 2002. SAS/STAT user's guide, release 9.1 edition. SAS Inst., Inc., Cary, NC.

Tan, Z., Y. Hong, and C. Hu. 2003. In vitro culture of Magnolia grandiflora. J. Hunan Agr. Univ. 29:478-481 (abstr.).

Thomas, T.D. 2008. The role of activated charcoal in plant tissue culture. Biotechnol. Adv. 26: 618-631.

Tong, Z., Y. Zhu, and Z. Wang. 2002. Studies on tissue culture and the establishment of a highyield cell line of Magnolia officinalis. J. Nanjing For. Univ. 26:23-26 (abstr.).

United States National Arboretum. (2003). Magnolia 'Ann', 'Betty', 'Jane', 'Judy', 'Pinkie' 'Randy', 'Ricki', and 'Susan'. 10 Nov. 2009. <http:// www.usna.usda.gov/Newintro/magnoli1.html>.

Werbrouck, S.P.O., M.S. Strnad, H.A. van Onckelen, and P.C. Debergh. 1996. Meta-topolin, an alternative to benzyladenine in tissue culture? Physiol. Plant. 98:2. 